\title{
Model Auditory Intellectually Repetition (AIR) Berbantuan Video Pembelajaran untuk Meningkatkan Pemahaman Siswa
}

\author{
Yuniar Purwanti ${ }^{\# 1}$, Munira Habibah Putri ${ }^{* 2}$, Dian Rahadian ${ }^{\# 3}$ \\ ${ }^{\# 1}$ Pendidikan Teknologi Informasi, Institut Pendidikan Indonesia \\ Jalan Pahlawan No. 32 Garut \\ ${ }^{1}$ yuniarlinstitutpendidikan.ac.id
}

\begin{abstract}
The ability to comprehension students in historical subjects is very necessary because students need to build new knowledge from previous experience and knowledge. The Auditory Intellectually Repetition (AIR) model assisted by learning videos is thought to be suitable for improving students' comprehension in History. The research objectives are 1) to find out whether there is an increase in students' comprehension of the History subject after applying the AIR model assisted video learning and 2) to find out whether the increase in student comprehensioning in the History subject applying the AIR model learning video assisted learning video is better compared to the who implemented learning videos. The research method which used in this study is the Quasi Experimental Design method which involves two classes of Social Sciences at SMAN 6 Garut as the control class and the experimental class. This study shows an increase in students' comprehension of history subjects both in the control class by 25.86 and in the experimental class by 38,47 which is statistically significantly different. Students' comprehensioning of the History subject based on the test showed that the experimental class improved more than the control class. Students' comprehensioning of history subjects shows an increase in both using the AIR method assisted by learning videos and learning videos. Improved student understanding is better on the AIR model assisted with learning videos.
\end{abstract}

Keywords: Auditory Intellectually Repetition (AIR) Model, learning videos, student's comprehension

Abstrak - Kemampuan siswa untuk memahami dalam mata pelajaran sejarah sangat diperlukan karena siswa perlu membangun pengetahuan baru dari pengalaman dan pengetahuan sebelumnya. Model Auditory Intellectually Repetition (AIR) berbantuan video pembelajaran dianggap sesuai untuk meningkatkan pemahaman siswa dalam Sejarah. Tujuan penelitian adalah 1) untuk mengetahui apakah ada peningkatan pemahaman siswa tentang mata pelajaran Sejarah setelah menerapkan model AIR dibantu dengan pembelajaran video dan 2) untuk mengetahui apakah peningkatan pemahaman siswa dalam mata pelajaran Sejarah menerapkan UDARA. video pembelajaran model video pembelajaran berbantuan lebih baik dibandingkan dengan yang menerapkan video pembelajaran. Metode penelitian yang digunakan dalam penelitian ini adalah metode Quasi Experimental Design yang melibatkan dua kelas Ilmu Sosial di SMAN 6 Garut sebagai kelas kontrol dan kelas eksperimen. Penelitian ini menunjukkan peningkatan pemahaman siswa tentang mata pelajaran sejarah baik di kelas kontrol dengan 25,86 dan di kelas eksperimen dengan 38,47 yang secara statistik berbeda nyata. Pemahaman siswa tentang mata pelajaran Sejarah berdasarkan Uji t menunjukkan bahwa kelas eksperimen meningkat lebih dari kelas kontrol. Pemahaman siswa tentang mata pelajaran sejarah menunjukkan peningkatan dalam menggunakan metode AIR dibantu oleh video pembelajaran dan video pembelajaran. Pemahaman siswa yang meningkat lebih baik pada model AIR yang dibantu dengan video pembelajaran.

Kata kunci: Model Auditory Intellectually Repetition (AIR), video pembelajaran, pemahaman siswa

\section{Pendahuluan}

Pemahaman merupakan kemampuan untuk menerangkan dan menginterprestasikan sesuatu, yang berarti bahwa seseorang telah memahami sesuatu atau telah memperoleh pemahaman akan mampu menerangkan atau menjelaskan kembali apa yang telah diterima. Siswa dikatakan memahami ketika mereka menghubungkan pengetahuan baru dengan pengetahuan lama. Siswa harus belajar sejarah dengan pemahaman dan secara aktif membangun pengetahuan baru dari pengalaman dan pengetahuan sebelumnya. Berdasarkan hasil pengamatan langsung di SMAN 6 Garut dan wawancara pada siswa khususnya kelas X MIPA, diperoleh hasil saat pembelajaran berlangsung guru hanya menggunakan pembelajaran konvensional dengan metode yang dianggap mudah, seperti menggunakan metode ceramah, media papan tulis atau buku, pembelajaran konvensional tanpa media yang menunjang mengakibatkan pembelajaran tersebut dianggap kurang menarik oleh siswa membuat siswa menjadi cepat bosan atau jenuh terhadap materi yang disampaikan, diduga berdampak pada nilai siswa yang rendah karena materi yang kurang dikuasai.

Arsyad [2], yang menyatakan bahwa media video yang digunakan dalam proses belajar mengajar memiliki banyak 
manfaat, diantaranya, video merupakan bahan pembelajaran yang dapat digunakan untuk menyampaikan pesan materi pelajaran. Sedangkan media video pembelajaran adalah media atau alat bantu mengajar yang berisi pesan-pesan pembelajaran, video sebagai media audio visual dan mempunyai unsur gerak akan mampu menarik perhatian dan motivasi siswa dalam melaksanakan kegiatan pembelajaran. Model pembelajaran AIR (Auditory Intellectually Repetition) adalah salah satu model pembelajaran yang menggunakan pendekatan pembelajaran kontruktivis, dimana siswa ditekankan untuk memanfaatkan semua alat indra yang mereka miliki, apabila dalam proses belajar mengajar banyak panca indra yang digunakan, maka peningkatan pemahaman siswa akan lebih baik [3].

Berdasarkan latar belakang dan batasan masalah tersebut, maka rumusan masalah pada penelitian ini, sebagai berikut :

1. Apakah terdapat peningkatan pemahaman siswa pada mata pelajaran Sejarah setelah menerapkan model AIR berbantuan video pembelajaran?

2. Apakah peningkatan pemahaman siswa pada mata pelajaran Sejarah yang menerapkan model AIR berbantuan video pembelajaran lebih baik daripada yang menerapkan video pembelajaran?

Adapun tujuan penelitiannya adalah, 1) untuk mengetahui apakah terdapat peningkatan pemahaman siswa pada mata pelajaran Sejarah setelah menerapkan model AIR berbantuan video pembelajaran dan 2) untuk mengetahui peningkatan pemahaman siswa pada mata pelajaran Sejarah yang menerapkan model AIR berbantuan video pembelajaran lebih baik daripada yang menerapkan video pembelajaran.

Berdasarkan tujuan penelitian, diharapkan memiliki manfaat dan kegunaan, baik 1) bagi siswa yaitu pembelajaran sejarah dengan model Auditory Intelectually Renpetition (AIR) yang dapat menumbuhkan semangat pada diri siswa untuk dapat memahami materi, 3) bagi guru yaitu untuk membantu guru dalam melaksanakan pembelajaran secara interaktif, aktif serta menambah wawasan dan pengetahuan dalam penyelenggaraan proses belajar mengajar dengan metode dan media mengajar yang bervariasi sehingga sangat memudahkan bagi guru dalam penyampaian materi kepada siswa, 4) bagi sekolah, memberikan masukan dalam mengembangkan suatu model pembelajaran sehingga mampu meningkatkan kemampuan pemahaman serta sumber daya pendidikan untuk menghasilkan output yang berkualitas, 5) bagi institusi pendidikan lainnya yaitu dapat menambah wawasan, pemahaman bagi peneliti serta gambaran yang jelas tentang pengembangan video pembelajaran model Auditory Intelectually Repetition (AIR) dalam pembelajaran sejarah sehingga dapat meningkatkan pemahaman pada diri siswa.

\section{METODE PENELITIAN}

Metode yang digunakan dalam penelitian ini adalah metode Quasi Eksperimental design (eksperimen semu). Menurut Sugiyono [4] desain ini memiliki kelompok kontrol, sehingga tidak dapat berfungsi sepenuhnya untuk mengontrol variabel-variabel luar yang mempengaruhi pelaksanaan eksperimen. Penelian ini berupaya untuk mengujicobakan penerapan model Auditory Intellectually Repetition (AIR) berbantuan video pembelajaran dalam meningkatkan pemahaman siswa pada mata pelajaran Sejarah, untuk mencapai hasil belajar yang diharapkan maka dengan menggunakan metode kuantitatif dengan menggunakan metode Quasi Eksperimen yang digunakan dalam penelitian ini adalah Pretest-Postest Control Group Design, dimana untuk penelitian ini terbagi ke dalam dua kelompok, yaitu kelompok kelas eksperimen dan kelompok kelas kontrol.

Untuk kelompok kelas eksperimen akan diberi perlakuan dengan menggunakan model Auditory Intellectually Repetition (AIR) berbantuan video pembelajaran, sedangkan untuk kelompok kelas kontrol menggunakan pembelajaran seperti halnya guru menggunakan model pembelajaran konvensional. Kedua kelompok diberikan pre-test, perlakuan yang berbeda antara kelas eksperimen dengan kelas kontrol, dan pre-test di akhir. Dalam penelitian ini sampel penelitian dipilih secara random. Adapun rancangan desain penelitian eksperimen Nonequievalent control group design dapat digambarkan dalam tabel sebagai berikut:

TABEL 1

PRETEST-POSTEST CONTROL GROUP DESIGN

\begin{tabular}{|l|c|c|c|}
\hline Kelompok & $\begin{array}{c}\text { Pre- } \\
\text { test }\end{array}$ & $\begin{array}{c}\text { Perlakuan } \\
\text { (Variabel } \\
\text { Bebas) }\end{array}$ & $\begin{array}{c}\text { Post-test } \\
\text { (Variabel } \\
\text { Terikat) }\end{array}$ \\
\hline Eksperimen & $\mathrm{O}_{1}$ & $X_{1}$ & $\mathrm{O}_{2}$ \\
\hline Kontrol & $\mathrm{O}_{2}$ & $X_{2}$ & $\mathrm{O}_{2}$ \\
\hline
\end{tabular}

Keterangan :

$\mathrm{O}_{1}:$ Pretest (test awal)

$\mathrm{O}_{2}:$ Posttest (test akhir)

$X_{1}$ : Perlakuan model (AIR) berbantuan video pembelajaran

$X_{2}$ : Perlakuan video pembelajaran

Penelitian ini bertempat di Sekolah Menengah Atas Negeri 6 Garut J1. Guntur Melati No.12, Haurpanggung, Tarogong Kidul, Kabupaten Garut, Jawa Barat 44151. Penelitian ini dilaksanakan di SMAN 6 Garut, karena berbagai pertimbangan antara lain: sesuai dengan kondisi yang dibutuhkan dalam penelitian ini dan belum ada penelitian sebelumnya tentang penelitian-penelitian yang akan dilakukan yaitu penerapan model Auditory Intellectually Repetition (AIR) berbantuan video pembelajaran dalam meningkatkan pemahaman siswa. Penelitian ini berfokus pada siswa kelas X, subjek penelitian 
ini berpusat pada jurusan IPS. Karena pada kelas IPS yang diajarkan lebih dalam bukan hanya dasar sejarah saja. Populasi dalam penelitian ini adalah seluruh siswa kelas X IPS SMAN 6 Garut pada tahun ajaran 2018//2019. Sampel yang akan diteliti adalah X IPS 1 dan X IPS 4 dengan jumlah siswa masing-masing adalah 37 orang.

Dalam penelitian ini instrument yang digunakan terdiri dari dua jenis, yaitu tes dan angket. Soal yang digunakan baik dalam pre-test maupun post-test soalnya sama, soal diuji cobakan terlebih dahulu kepada siswa yang telah mempelajari materi yang akan digunakan dalam penelitian ini.

Uji coba instrumen diberikan kepada salah satu populasi yang bukan subjek penelitian. Setelah itu instrumen di analisis untuk mengetahui validitas, reliabilitas, daya pembeda dan tingkat kesukaran.

Sundayana, [5] : 59, 69. 76. menjelaskan mengenai validitas, reliabilitas, daya pembeda dan tingkat kesukaran adalah sebagai berikut : 1) Validitas adalah suatu ukuran yang menunjukkan tingkat kevalidan atau kesahihan suatu instrumen. Suatu instrumen dikatakan valid apabila mampu mengukur apa yang diinginkan. Sebuah instrumen dikatakan valid apabila dapat mengungkapkan data dari variabel yang diteliti secara tepat. Tinggi rendahnya validitas instrumen menunjukan sejauh mana data yang terkumpul tidak menyimpang dari gambaran tentang variabel yang dimaksud, 2) Reliabilitas instrumen penelitian adalah suatu alat yang memberikan hasil yang tetap sama (konsisten, ajeg). Hasil pengukuran itu harus tetap sama (relatif sama) jika pengukurannya diberikan pada subyek yang sama meskipun dilakukan oleh orang yang berbeda, waktu yang berlainan, dan tempat yang berbeda pula. Tidak terpengaruh oleh pelaku, situasi dan kondisi. Alat ukur yang reabilitasnya tinggi disebut alat ukur yang reliabel menurut (Sundayana, 2015, hlm. 69). Dalam pengujian reabilitas instrumen penelitian ini menggunakan rumus Cronbach's Alpha $(\alpha)$, 3) Daya Pembeda suatu soal adalah kemampuan suatu soal untuk dapat membedakan antara siswa yang berkemampuan tinggi dan siswa yang berkemampuan rendah, 4) Tingkat kesukaran adalah keberadaan suatu butir soal apakah dipandang sukar, sedang, atau mudah dalam mengerjakannya.

Langkah-langkah dalam melakukan pengumpulan data yang dilakukan oleh peneliti sebagai berikut:

a. Tes awal (pretest)

Tes awal dilakukan sebelum pembelajaran berlangsung untuk mengetahui kemampuan awal antara kedua kelas baik kelas eksperimen maupun kelas kontrol.

b. Treatment

1. Kelas eksperimen diberikan perlakuan dengan menggunakan model Auditory Intellectually Repetition (AIR) berbantuan video pembelajaran.

2. Kelas kontrol hanya diberikan perlakuan dengan video pembelajaran.

Tes akhir (posttest)
Tes akhir dilakukan setelah pembelajaran berlangsung atau setelah kedua kelas mendapat perlakuan sistem pengajaran yang berbeda. Tujuan dari tes akhir ini adalah untuk mengetahui apakah terdapat peningkatan pemahaman siswa setelah mendapat perlakuan pembelajaran.

Dalam penelitian ini, peneliti menggunakan teknik analisis data dengan pendekatan kuantitatif. Berdasarkan desain penelitian, teknik pengumpulan data yang digunakan dalam penelitian ini adalah berupa tes objektif pretest (tes awal) dan posttest (tes akhir). Data tersebut dianalisis dengan langkah-langkah sebagai berikut: pemberian skor dan pengujian terhadap hipotesis. Pada umumnya pengujian terhadap hipotesis dapat dilakukan dengan uji parametrik dan non-parametrik. Uji parametrik dapat dilakukan jika asumsi-asumsi penelitian parametrik dipenuhi, antara lain jika data dalam pengujian hipotesis ini, data yang dimaksud ialah peningkatan (gain) skor yang dicapai kedua kelas bersifat normal dan memiliki varians yang homogen.

Jika asumsi-asumsi penelitian parametrik tersebut tidak terpenuhi, maka pengujian terhadap hipotesis harus dilakukan dengan uji non-parametrik. Oleh karena itu, untuk mengetahui pengujian statistik mana yang tepat, sebelumnya perlu diketahui normalitas dan homogenitas dari gain kedua kelas.

a. Uji Normalitas

Uji normalitas dilakukan dengan tujuan untuk mengetahui apakah data diambil dari perolehan skor siswa berdistribusi normal atau tidak dan ini dilakukan terhadap data pretest dan posttest dari kedua kelompok, yaitu kelompok eksperimen dan kelompok kontrol. Uji normalitas dalam penelitian ini menggunakan Uji Lilliefors yaitu pengujian yang biasa digunakan. Pada data diskrit, yaitu data berbentuk sebaran atau tidak disajikan dalam bentuk interval dan untuk perhitungan Uji Lilliefors ini menggunakan aplikasi Microsoft Excel. Langkah-langkah uji Lilliefors yaitu:

1. Menghitung nilai rata-rata dan simpangan bakunya.

2. Susunlah data dari yang terkecil sampai yang terbesar pada tabel.

3. Mengubah nilai $\mathrm{x}$ pada nilai $\mathrm{z}$ dengan rumus:

$$
z=\frac{x-\bar{x}}{s}
$$

4. Menghitung luas $z$ dengan menggunakan tabel $z$

5. Menentukan nilai proporsi data yang lebih kecil atau sama dengan data tersebut

6. Menghitung luas $\mathrm{z}$ dengan nilai proporsi

7. Menentukan luas maksimum ( $\left.\mathrm{L}_{\text {maks }}\right)$

8. Menentukan luas tabel lilliefors $\left(\mathrm{L}_{\text {tabel }}\right)$; $\mathrm{L}_{\text {tabel }}=$ $L_{\alpha}(n-1)$

9. Kriteria kenormalan: jika $L_{\text {maks }} \leq L_{\text {tabel }}$ maka data berdistribusi normal

\section{b. Uji Homogenitas Dua Varians}

Uji homogenitas merupakan suatu uji yang dilakukan untuk melihat kedua kelas yang diteliti homogen atau tidak homogen. Pada penelitian ini pengujian homogenitasnya 
diuji dengan cara menguji data nilai pretest sebelumnya dengan menggunakan aplikasi Microsoft Excel. Pengujian homogenitas pada penelitian ini menggunakan uji $\mathrm{F}$ dengan rumus:

$$
F_{\text {hitung }}=\frac{\text { var iansbesar }}{\text { var ians kecil }}
$$

Kriteria pengujian:

Jika $F_{\text {hitung }} \geq F_{\text {tabel }}$ tidak homogen

Jika $F_{\text {hitung }} \leq \mathrm{F}_{\text {tabel }}$ homogen c. Uji $t$

Setelah data hasil penelitian diketahui sebaran datanya berdistribusi normal, serta mempunyai varians yang homogen, maka uji t dapat di gunakan dengan langkahlangkah sebagai berikut:

1. Merumuskan hipotesis nol dan hipotesis alternatifnya

2. Menentukan nilai $t_{\text {hitung }}$ dengan rumus:

$t_{\text {hitung }}=\frac{x_{1}-x_{2}}{S \text { gabung } \sqrt{\frac{n_{1+n_{2}}}{n_{1 . n_{2}}}}}$

dengan $S_{\text {gabung }}=\sqrt{\frac{\left(n_{1}-1 S^{2}+\left(n_{2}-1\right) S_{2}^{2}\right.}{n_{1}+n_{2}-2}}$

3. Menentukan nilai $\mathrm{t}_{\text {tabel }}=\mathrm{t}_{\alpha}\left(\mathrm{dk}=\mathrm{n}_{1}+\mathrm{n}_{2}-2\right)$

4. Kriteria pengujian hipotesis:

Jika $-\mathrm{t}_{\text {tabel }} \leq \mathrm{t}_{\text {hitung }} \leq \mathrm{t}_{\text {tabel }}$ maka $\mathrm{H}_{0}$ diterima

\section{d. Uji Gain Ternormalisasi}

Pada saat hasil penelitian dengan kemampuan awal berbeda, atau ingin mengetahui bagaimana peningkatan hasil belajar, maka kita gunakan gain ternormalisasi. Gain ternormalisasi (g) untuk memberikan gambaran umum peningkatan kemampuan pemahaman siswa dan kemampuan pemecahan masalah statistik antara sebelum dan sesudah pembelajaran. Besarnya peningkatan sebelum dan sesudah pembelajaran di hitung dengan rumus gain ternormalisasi dengan menggunakan aplikasi Microsoft Excel.

\section{HASIL PENELITIAN DAN PEMBAHASAN}

Data hasil belajar siswa pada mata pelajaran Sejarah berdasarkan pada tujuan yang telah dirumuskan atau ditentukan meliputi nilai pretest dan posttest dari kedua kelompok yang berbeda. Kelompok eksperimen dalam pembelajaran menggunakan media video pembelajaran dengan model Auditory Intellectually Repetition (AIR) sebanyak 37 siswa dan kelompok kontrol dalam pembelajaran menggunakan media video pembelajaran sebanyak 37 siswa.

Penelitian ini menghasilkan data skor hasil pretest dan posttest dalam peningkatan pemahaman siswa, baik pada kelas kontrol dan kelas eksperimen. Analisis dilakukan terhadap hasil belajar siswa baik sebelum maupun setelah dilakukan proses pembelajaran dengan penggunaan video pembelajaran model Auditory Intellectually Repetition
(AIR) pada kelas eksperimen dan pembelajaran menggunakan video pembelajaran pada kelas kontrol, sehingga diperoleh informasi seperti yang tertera pada tabel 2 dibawah ini.
TABEL 2

DATA HASIL PENELITIAN

\begin{tabular}{|c|c|c|c|c|}
\hline \multirow{2}{*}{ Keterangan } & \multicolumn{2}{|c|}{ Kelas Kontrol } & \multicolumn{2}{c|}{ Kelas Eksperimen } \\
\cline { 2 - 5 } & Pretest & Posttest & Pretest & Posttest \\
\hline Jumlah Siswa & 37 & 37 & 37 & 37 \\
\hline Skor Ideal & 100 & 100 & 100 & 100 \\
\hline Nilai Terbesar & 50 & 70 & 57 & 90 \\
\hline Nilai Terkecil & 13 & 50 & 27 & 70 \\
\hline Rata-Rata & 31,89 & 57,75 & 40,09 & 78,56 \\
\hline $\begin{array}{c}\text { Simpangan } \\
\text { Baku }\end{array}$ & 8,87 & 5,16 & 6,50 & 4,94 \\
\hline
\end{tabular}

Setelah data yang dibutuhkan sudah terkumpul, maka dilakukan analisis data untuk mengetahui hasil dari penelitian dengan melihat apakah hipotesis yang diajukan diterima atau ditolak. Adapun hasil penelitian yang dilakukan adalah sebagai berikut:

a. Uji Normalitas Tes Awal (Pretest)

Uji normalitas data digunakan untuk mengetahui jenis statistik apa yang digunakan untuk pengolahan data selanjutnya. Dalam uji ini, peneliti menggunakan Uji Lilliefors dengan taraf signifikan $(\alpha)$ sebesar 5\% yang hasilnya dapat dilihat di bawah ini:

Hipotesis Pengujian:

$\mathrm{H}_{0}$ : Sebaran data berdistribusi normal

$\mathrm{Ha}$ : Sebaran data tidak berdistribusi normal

Kriteria Pengambilan Keputusan:

Jika $\mathrm{L}_{\text {maks }}<\mathrm{L}_{\text {tabel }}$ maka data berdistribusi normal

Jika $\mathrm{L}_{\text {maks }}>\mathrm{L}_{\text {tabel }}$ maka data berdistribusi tidak normal

Setelah dilakukan perhitungan dengan Uji Lilliefors, maka diperoleh hasil yang tertera pada tabel 3 dibawah ini:

TABEL 3

HASIL UJI NORMALITAS TES AWAL (PRETEST) DENGAN UJI LILLIEFORS

\begin{tabular}{|l|l|l|l|}
\hline Kelas & Lmaks & Ltabel & Keterangan \\
\hline Kontrol & 0,125 & 0,148 & $\begin{array}{l}\text { Data Berdistribusi } \\
\text { Normal }\end{array}$ \\
\hline Eksperimen & 0,142 & 0,148 & Data Berdistribusi \\
\hline
\end{tabular}




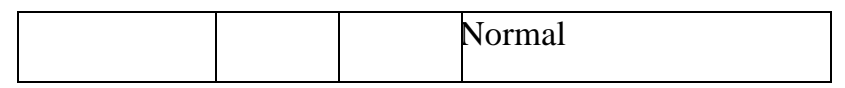

Dari hasil perhitungan uji normalitas data hasil pretest kelas yang menggunakan video pembelajaran model Auditory Intellectually Repetition (AIR) (Eksperimen) diperoleh $\mathrm{L}_{\text {maks }}=0,142$ lebih kecil dari $\mathrm{L}_{\text {tabel }}=0,148$, maka sebaran data tersebut berdistribusi normal, sedangkan data hasil pretest kelas yang menggunakan video pembelajaran (kontrol) diperoleh $\mathrm{L}_{\text {maks }}=0,125$ lebih kecil dari $\mathrm{L}_{\text {tabel }}=0,148$, maka sebaran data berdistribusi normal.

a.Uji Normalitas Tes Akhir (Posttest)

Uji normalitas data digunakan untuk mengetahui jenis statistik apa yang digunakan untuk pengolahan data selanjutnya. Dalam uji ini, peneliti menggunakan Uji Lilliefors dengan taraf signifikan $(\alpha)$ sebesar 5\% yang hasilnya dapat dilihat di bawah ini:

Hipotesis Pengujian:

$\mathrm{H}_{0}$ : Sebaran data berdistribusi normal

Ha : Sebaran data tidak berdistribusi normal

Kriteria Pengambilan Keputusan:

Jika $\mathrm{L}_{\text {maks }}<\mathrm{L}_{\text {tabel }}$ maka data berdistribusi normal

Jika $\mathrm{L}_{\text {maks }}>\mathrm{L}_{\text {tabel }}$ maka data berdistribusi tidak normal

Setelah dilakukan perhitungan dengan Uji Lilliefors, maka diperoleh hasil yang tertera pada tabel 4 dibawah ini:

TABEL 4

HASIL UJI NORMALITAS TES AKHIR (POSTTEST) DENGAN UJI LILLIEFORS

\begin{tabular}{|c|r|r|l|}
\hline Kelas & maks & tabel & \multicolumn{1}{|c|}{ Keterangan } \\
\hline Kontrol &, 125 &, 148 & $\begin{array}{l}\text { Data Berdistribusi } \\
\text { Normal }\end{array}$ \\
\hline Eksperimen &, 142 &, 148 & $\begin{array}{l}\text { Data Berdistribusi } \\
\text { Normal }\end{array}$ \\
\hline
\end{tabular}

Dari hasil perhitungan uji normalitas data hasil posttest, kelas yang menggunakan video pembelajaran model Auditory Intellectually Repetition (AIR) (Kelas Eksperimen) diperoleh $\mathrm{L}_{\text {maks }}=0,142$ lebih kecil dari $\mathrm{L}_{\text {tabel }}=0,148$, maka sebaran data tersebut berdistribusi normal, sedangkan data hasil posttest kelas yang menggunakan video pembelajaran (Kelas Kontrol) diperoleh $\mathrm{L}_{\text {maks }}=0,125$ lebih kecil dari $\mathrm{L}_{\text {tabel }}$ $=0,148$, maka sebaran data tersebut berdistribusi normal. Karena kedua data berdistribusi normal, maka perhitungan selanjutnya menggunakan uji statistik parametrik yaitu Uji Homogenitas Dua Varians.

\section{b.Uji Homogenitas Dua Varians}

Setelah dilakukan uji normalitas, maka perhitungan selanjutnya menggunakan uji homogenitas dua varians.
Hasil uji homogenitas dua varians dapat dilihat pada tabel 5 dibawah ini:

TABEL 5

HASIL UJI HOMOGENITAS PRETEST

\begin{tabular}{|c|c|c|c|c|c|}
\hline Kelas & N & Rerata & SB & $\mathbf{F}_{\text {hitung }}$ & $\mathbf{F}_{\text {tabel }}$ \\
\hline Kontrol & 37 & 57,75 & 5,16 & 1,09 & 2,21 \\
\hline Eksperimen & 37 & 78,56 & 4,94 & 1,09 & 2,21 \\
\hline \multicolumn{7}{|c|}{ Keterangan } & Homogen \\
\hline
\end{tabular}

Merumuskan Hipotesis:

$\mathrm{H}_{0}$ : Kedua varians homogen $\left(\mathrm{v}_{1}=\mathrm{v}_{2}\right)$

$\mathrm{H}_{\mathrm{a}}$ : Kedua varians tidak homogen $\left(\mathrm{v}_{1} \neq \mathrm{v}_{2}\right)$

Kriteria Pengambilan Keputusan

Jika $\mathrm{F}_{\text {hitung }} \mathrm{F}_{\text {tabel }}$ maka $\mathrm{H}_{0}$ diterima

Jika $\mathrm{F}_{\text {hitung }} \mathrm{F}_{\text {tabel }}$ maka $\mathrm{H}_{\mathrm{a}}$ diterima

Dari hasil perhitungan uji homogenitas dua varians diperoleh $F_{\text {hitung }}=1,86 \mathrm{~F}_{\text {tabel }}=2,21$ sehingga varians kedua kelompok homogen.

TABEL 6

HASIL UJI HOMOGENITAS POSTTEST

\begin{tabular}{|c|c|c|c|c|c|}
\hline Kelas & $\mathbf{N}$ & Rerata & SB & $\mathbf{F}_{\text {hitung }}$ & $\mathbf{F}_{\text {tabel }}$ \\
\hline Kontrol & 37 & 57,75 & 5,16 & 1,09 & 2,21 \\
\hline Eksperimen & 37 & 78,56 & 4,94 & 1,09 & 2,21 \\
\hline \multicolumn{5}{|c|}{ Keterangan } & Homogen \\
\hline
\end{tabular}

Dari hasil perhitungan uji homogenitas dua varians diperoleh $\mathrm{F}_{\text {hitung }}=1,09 \mathrm{~F}_{\text {tabel }}=2,21$ sehingga varians kedua kelompok homogen.

\section{c.Uji Hipotesis}

Uji Perbandingan Kemampuan Awal (Pretest)

Data hasil perbandingan kemampuan awal kedua kelas pada penelitian ini menggunakan uji $\mathrm{t}$ (independent sample $t$ test) karena kedua datanya bervarians homogen. Dalam uji $\mathrm{t}$ dengan taraf signifikan 5\%, hasilnya dapat dilihat di bawah ini:

Rumusan hipotesis nol dan hipotesis alternatifnya:

$\mathrm{H}_{0}$ : Tidak terdapat perbedaan pemahaman antara siswa yang mendapatkan pembelajaran video pembelajaran model Auditory Intellectually Repetition (AIR) dengan siswa yang menggunakan video pembelajaran.

$\mathrm{H}_{\mathrm{a}}$ : Terdapat perbedaan pemahaman siswa yang lebih baik antara siswa yang menggunakan video pembelajaran 
model Auditory Intellectually Repetition (AIR) dengan siswa yang menggunakan video pembelajaran.

Kriteria pengujian hipotesis:

$\mathrm{H}_{0}$ diterima jika $\mathrm{t}_{\text {tabel }} \leq \mathrm{t}_{\text {hitung }}$

Karena nilai $\mathrm{t}_{\text {hitung }}=-4,577$ dan $\mathrm{t}_{\text {tabel }}=1,993$ dapat disimpulkan bahwa hipotesis $\mathrm{H}_{0}$ diterima dan hipotesis $\mathrm{H}_{\mathrm{a}}$ ditolak yaitu tidak terdapat perbedaan pemahaman antara siswa yang mendapatkan model Auditory Intellectually Repetition (AIR) berbantuan video pembelajaran dengan siswa yang hanya menggunakan video pembelajaran . Untuk data uji t sampel nya bisa dilihat di tabel 7 dibawah ini:

TABEL 7

HASIL UJI T PRETEST KONTROL DAN EKSPERIMEN

\begin{tabular}{|c|c|c|c|c|}
\hline \multicolumn{2}{|c|}{ Uji t Sampel Pretest Kontrol dan Eksperimen } \\
\hline Uji Data & $\mathbf{N}$ & $\mathbf{M}$ & $\mathbf{S}$ & $\mathbf{S}^{\wedge} \mathbf{2}$ \\
\hline Kontrol & 37 & 31,89 & 8,87 & 78,73 \\
\hline Eksperimen & 37 & 40,09 & 6,50 & 42,28 \\
\hline \multicolumn{2}{|c|}{$\mathrm{R}$} & $=$ & \multicolumn{2}{c|}{0,02} \\
\hline $\mathrm{V}$ & $=$ & \multicolumn{2}{c|}{$-4,577$} \\
\hline \multicolumn{2}{|c|}{$\mathrm{T}_{\text {hitung }}$} & $=$ & \multicolumn{2}{|c|}{1,993} \\
\hline t 0,95 (72) & $=$ & \multicolumn{2}{|c|}{$\mathrm{H}_{0}$ diterima } \\
\hline $\begin{array}{c}\text { Keputusan } \\
\text { Hipotesis }\end{array}$ & $=$ & \\
\hline
\end{tabular}

\section{Uji Perbandingan Kemampuan Akhir (Posttest)}

Dalam analisis data hasil perbandingan kemampuan akhir kedua kelas pada penelitian ini menggunakan uji $\mathrm{t}$ (independent sample t test) karena kedua datanya bervarians homogen. Dalam uji t dengan taraf signifikan 5\%, hasilnya dapat dilihat dibawah ini:

Rumuskan hipotesis nol dan hipotesis alternatifnya:

$\mathrm{H}_{0}$ : Penerapan model Auditory Intellectually Repetition (AIR) berbantuan video pembelajaran pada mata pelajaran Sejarah tidak lebih meningkatkan pemahaman siswa Kelas X di SMA Negeri 6 Garut dibandingkan dengan penerapan pembelajaran dengan menggunakan video pembelajaran.

$\mathrm{H}_{\mathrm{a}}$ : Penerapan model Auditory Intellectually Repetition (AIR) berbantuan video pembelajaran pada mata pelajaran Sejarah lebih meningkatkan pemahaman siswa Kelas $\mathrm{X}$ di SMAN Negeri 6 Garut dibandingkan dengan penerapan pembelajaran dengan video pembelajaran.

Kriteria pengujian hipotesis:

$\mathrm{H}_{0}$ diterima jika $\mathrm{t}_{\text {tabel }} \leq \mathrm{t}_{\text {hitung }}$

Karena nilai $t_{\text {hitung }}=17,908$ dan $t_{\text {tabel }}=1,993$ dapat disimpulkan bahwa hipotesis $\mathrm{H}_{0}$ ditolak dan hipotesis $\mathrm{H}_{\mathrm{a}}$ diterima yaitu penerapan model Auditory Intellectually Repetition (AIR) berbantuan video pembelajaran pada mata pelajaran Sejarah lebih meningkatkan pemahaman siswa pada Kelas X di SMA Negeri 6 Garut dibandingkan dengan penerapan pembelajaran dengan menggunakan video pembelajaran. Untuk data uji t sampelnya bisa dilihat di tabel 4.9 dibawah ini:

TABEL 8

HASIL UJI T POSTTEST KONTROL DAN EKSPERIMEN Uji t Sampel Pretest Kontrol dan Eksperimen

\begin{tabular}{|c|c|c|c|c|}
\multicolumn{5}{|c|}{ Eksperimen } \\
\hline Uji Data & $\mathbf{N}$ & $\mathbf{M}$ & $\mathbf{S}$ & $\mathbf{S}^{\wedge} \mathbf{2}$ \\
\hline Kontrol & 37 & 57,75 & 5,16 & 26,58 \\
\hline Eksperimen & 37 & 78,56 & 4,94 & 24,41 \\
\hline $\mathrm{R}$ & $=$ & 0,02 \\
\hline $\mathrm{V}$ & $=$ & \multicolumn{2}{|c|}{72} \\
\hline $\mathrm{T}_{\text {hitung }}$ & $=$ & \multicolumn{2}{|c|}{17,908} \\
\hline $\mathrm{t}$ 0,95 (72) & $=$ & \multicolumn{2}{|c|}{1,993} \\
\hline $\begin{array}{c}\text { Keputusan } \\
\text { Hipotesis }\end{array}$ & $=$ & \multicolumn{2}{|c|}{$\mathrm{H}_{0}$ ditolak } \\
\hline
\end{tabular}

Pembahasan Hasil Penelitian

Peningkatan Pemahaman Siswa Pada Kelas Kontrol dan Kelas Eksperimen

a.Hasil Peningkatan Pemahaman Siswa Menggunakan Video Pembelajaran (Kelas Kontrol)

Belajar adalah suatu proses yang ditandai dengan perubahan pada diri seseorang. Perubahan sebagai hasil dari proses yang ditandai dengan perubahan pada diri seseorang. Perubahan sebagai hasil dari proses belajar dapat ditunjukan dalam bentuk perubahan pengetahuan, pemahaman, sikap dan tingkah laku keterampilan, kecakapan, kebiasaan serta perubahan aspek-aspek lain yang ada pada diri individu yang sedang belajar. Sedangkan menurut Winkel dan Mukhtar dalam Sudaryono [5] pemahaman merupakan kemampuan seseorang untuk menangkap makna dan arti dari bahan yang dipelajari, yang ditanyakan dengan menguraikan isi pokok dari suatu bacaan atau mengubah data yang disajikan dalam bentuk tertentu ke bentuk yang lain.

Surya (2004, hlm. 78) menyatakan bahwa proses pengajaran yang efektif dapat terbentuk melalui pengajaran yang memiliki ciri-ciri dalam proses pembelajarannya, yakni metode mengajar yang digunakan hendaknya sedemikian rupa bervariasi sesuai dengan tujuan dan bahan yang diajarkan [6]. Dengan metode mengajar yang bervariasi akan membuat siswa lebih senang dan lebih bersemangat dalam belajar, sehingga dapat memberikan hasil pembelajaran yang lebih baik. Sesuai dengan pendapat Sanjaya [7] (2010, hlm. 169) bahwa pengetahuan yang diperoleh siswa akan semakin abstrak apabila hanya disampaikan melalui bahasa verbal yang memungkinkan terjadinya verbalisme dalam belajar, artinya bahwa penggunaan media dalam pembelajaran agar pengalaman siswa dalam belajar lebih konkret, pesan 
yang disampaikan benar-benar mencapai tujuan yang ingin dicapai, dapat mendekatkan siswa dengan kondisi yang sebenarnya. Dengan demikian, dapat dikatakan bahwa media video pada dasarnya akan mendukung proses pembelajaran yang lebih utuh, siswa lebih aktif dan kreatif bagi siswa khususnya dalam memperoleh pengalaman dan perilaku sesuai dengan pengalaman masing-masing.

Pada penelitian yang dilakukan pada kelas X IPS 4 terjadi peningkatan pemahaman siswa yang menggunakan video pembelajaran hal ini dapat dilihat dari hasil pretest dan posttest kelas kontrol karena kelas kontrol adalah kelas yang menggunakan video pembelajaran. Dengan menggunakan video pembelajaran membuat siswa lebih tertarik serta mudah mengingat dan memahami materi yang diajarkan.

Munir [8] (2013, hlm. 295) menyebutkan bahwa dengan menggunakan video pembelajaran memiliki kelebihan antara lain: (1) menjelaskan keadaan riel dari suatu proses, fenomena atau kejadian; (2) sebagai bagian terintegrasi dengan media lain seperti teks atau gambar, video dapat memperkarya penyajian/penjelasan; (3) pengguna dapat melakukan pengulangan (replay) pada bagian-bagian tertentu untuk melihat gambaran yang lebih fokus; (4) sangat cocok untuk mengajarkan materi dalam ranah perilaku atau psikomotor; (5) kombinasi video dan audio dapat lebih efektif dan lebih cepat menyampaikan pesan dibandingkan media teks; (6) menunjukan dengan jelas suatu langkah prosedural.

Pada hari pertama penelitian dilakukan di kelas kontrol, dimana pada tahap pertama dilakukan pretest selama 45 menit untuk mengetahui pengetahuan awal dari siswa, kemudian kegiatan berikutnya diadakan pembelajaran sesuai dengan RPP yang telah disusun selama 3 jam $(3 \times 45$ menit $)$ menggunakan video pembelajaran dengan pembahasan materi kehidupan manusia dalam dimensi sejarah. Pembelajaran berlangsung seperti biasa dimana guru (peneliti) menjadi pusat pembelajaran dengan tanya jawab antara siswa dan guru (peneliti). Pada tahap akhir atau setelah pembelajaran berakhir dilaksanakan posttest dengan waktu mengerjakan 45 menit untuk mengetahui hasil belajar siswa setelah pemberian perlakuan dengan menggunakan video pembelajaran.

Pada kelas kontrol setelah dilaksanakan tes awal (pretest) yang bertujuan untuk mengetahui kemampuan awal siswa sebelum diberikan pembelajaran diperoleh rata-rata nilai pretest yaitu 31,89. Setelah tes awal (pretest) dilaksanakan, dilanjutkan dengan proses pembelajaran yang berakhir dengan tes akhir (posttest) untuk melihat sampai mana peningkatan kemampuan siswa setelah diberikan pembelajaran, sehingga diperoleh rata-rata nilai yaitu 57,75. Hasil dari pretest dan posttest pada kelas kontrol dalat dilihat pada gambar di bawah ini.

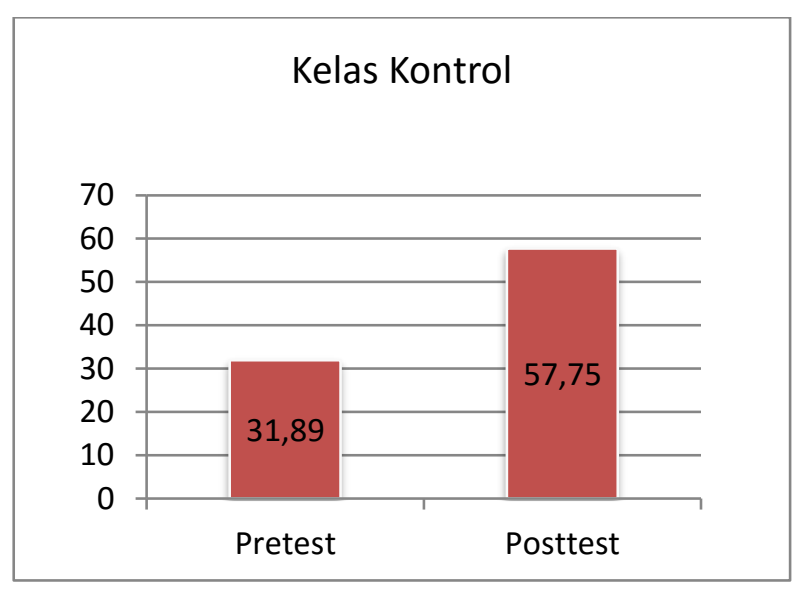

Gambar 1

Hasil Pretest dan Posttest Kelas Kontrol

Berdasarkan Gambar 4.2 diatas, dapat disimpulkan bahwa peningkatan pemahaman siswa pada kelas kontrol pada saat tes awal dan tes akhir memperoleh peningkatan sebanyak rata-rata 25,86 . Hal ini terjadi karena pada saat tes awal di kelas kontrol belum mendapatkan perlakuan proses pembelajaran, sedangkan pada saat proses pembelajaran telah dilaksanakan (adanya perlakuan) dan tes akhir dilakukan, ternyata mendapatkan perubahan peningkatan pemahaman siswa yang berbeda.

b. Hasil Peningkatan Pemahaman Siswa Pada Pembelajaran Yang Menggunakan Video Pembelajaran Model Auditory Intellectually Repetition (AIR) (Kelas Eksperimen)

Media pembelajaran merupakan alat yang dapat membantu proses belajar mengajar dan berfungsi untuk memperjelas makna pesan yang disampaikan guru, sehingga dapat mencapai tujuan pembelajaran dengan lebih baik dan sempurna. Media pembelajaran merupakan sarana untuk meningkatkan kegiatan proses belajar mengajar [9]. (Kustandi, 2013, hlm. 8). Media video pembelajaran merupakan media yang menyajikan audio dan visual berisi materi pembelajaran seperti konsep, prinsip prosedur, teori aplikasi pengetahuan untuk membantu pemahaman siswa terhadap materi pembelajaran [10] (Riyana, 2007, hlm. 120). Dengan adanya media video dalam pembelajaran, guru terbantu ketika menyampaikan materi dan suasana belajar tidak monoton, serta akan membantu siswa dalam memahami materi dengan mudah. Sedangkan model pembelajaran Auditory Intellectually Repetition (AIR) merupakan salah satu model pembelajaran yang menekankan bahwa belajar haruslah memanfaatkan semua alat indra yang dimiliki siswa [11] (Manurung, 2006, hlm. 98). Dengan demikian pada pembelajaran Auditory Intellectually Repetition (AIR) pembelajaran difokuskan pada pemberian pengalaman belajar secara langsung dan menyenangkan. Pengalaman belajar secara langsung dengan 
cara belajar mendengarkan atau menyimak (auditory), belajar dengan berfikir (intellectually) dan belajar dengan pengulangan (repetition).

Menurut Edgar Dale memaparkan tentang Cone of Experience (kerucut pengalaman), bahwa siswa akan mendapatkan pengalaman belajar yang lebih apabila mendapatkan pembelajaran dengan menggunakan multimedia (gabungan antara animasi, audio, video, dan teks) dibandingkan dengan pembelajaran metode verbal dalam penyampaian materi. Sehingga jelaslah bahwa kemampuan ingatan akan lebih tinggi pada siswa yang mendapatkan pembelajaran dengan bantuan media video dibandingkan dengan siswa yang hanya mendapatkan pembelajaran dengan metode biasa yang hanya mengandalkan teknik verbal atau ceramah. Dengan metode biasa, informasi mungkin bisa disimpan oleh otak, akan tetapi hanya sementara sehingga pada saat terjadi proses pemanggilan kembali informasi menjadi lebih lambat dan sulit. Sementara dengan video, adanya gambar memicu atau merangsang otak untuk selalu ingat dan mudah apabila dilakukan pemanggilan informasi tersebut.

Terlepas dari pengertian diatas sebuah media pembelajaran memiliki faktor yang sangat penting dalam keberhasilan belajar, seperti yang dikemukakan oleh hamalik (1986) bahwa pemakaian media pembelajaran dalam proses belajar mengajar dapat membangkitkan keinginan dan minat yang baru, dan bahkan membawa pengaruh-pengaruh psikologi terhadap siswa. Penggunaan media pembelajaran pada tahap orientasi pembelajaran akan sangat membantu keefektifan proses pembelajaran dan penyampaian pesan dan isi pelajaran pada saat itu.

Pada penelitian ini yang dilakukan di kelas X IPS 1 terdapat peningkatan pemahaman siswa yang menggunakan model Auditory Intellectually Repetition (AIR) berbantuan video pembelajaran hal ini dapat dilihat dari hasil pretest dan posttest kelas eksperimen karena kelas eksperimen adalah kelas yang menggunakan media video pembelajaran model Auditory Intellectually Repetition. Pada tahap pertama dilakukan pretest selama 45 menit untuk mengetahui pengetahuan awal kemudian kegiatan berikutnya dilakukan pembelajaran sesuai dengan RPP yang telah disusun selama 3 jam $(3 \times 45$ menit $)$ sesuai jadwal yang telah ditentukan. Karena materi yang dijadikan penelitian merupakan materi yang belum dipelajari dengan menggunakan penerapan model Auditory Intellectually Repetition (AIR) berbantuan video pembelajaran. Kegiatan selanjutnya masuk pada pembahasan materi kehidupan manusia dalam dimensi sejarah.

Pada kelas eksperimen penerapan model Auditory Intellectually Repetition (AIR) berbantuan video pembelajaran dilakukan dengan cara sebagai berikut:

1. Terlebih dahulu guru (peneliti) menjelaskan model pembelajaran yang akan dilaksanakan
2. Kemudian guru (peneliti) menayangkan sebuah video yang sudah dikemas ke dalam video pembelajaran selama 15 menit.

3. Setelah itu peserta didik dipersilahkan untuk mempelajari materi yang sudah di tayangkan oleh guru (peneliti), serta melakukan diskusi kelompok.

4. Kemudian guru (peneliti) memberikan soal atau permasalahan kepada peserta didik yang langkah selanjutnya didiskusikan.

5. Selanjutnya apabila soal yang sudah diberikan guru (peneliti) sudah dikerjakan, kemudian dari setiap kelompok mempresentasikan hasil dari diskusinya.

Penelitian yang dilakukan di kelas eksperimen dengan mata pelajaran Sejarah pokok bahasan kehidupan manusia dalam dimensi Sejarah dengan menggunakan penerapan model Auditory Intellectually Repetition (AIR) berbantuan video pembelajaran, setelah selesai pelaksanaan proses pembelajaran dan tes akhir, diperoleh hasil rata-rata pretest dan posttest yang dapat dilihat pada gambar dibawah ini:

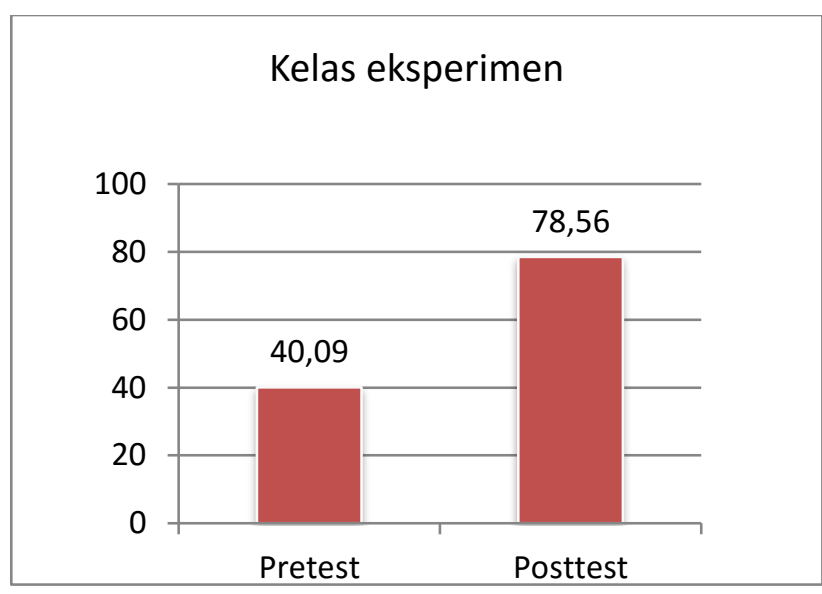

Gambar 2

Hasil Pretest dan Posttest Kelas Eksperimen

Berdasarkan hasil penelitian diperoleh kesimpulan bahwa peningkatan siswa yang menggunakan model Auditory Intellectually Repetition (AIR) berbantuan video pembelajaran pada tes awal dan tes akhir meningkatkan yang signifikan, sesuai dengan hasil pengolahan data ratarata nilai tes awal dan tes akhir yang tertera pada tabel 4.11. Pada tes awal (pretest), kelas eksperimen memperoleh ratarata sebanyak 40,09, sedangkan pada tes akhir (posttest) diperoleh rata-rata sebanyak 78,56, dari kedua tes tersebut terdapat peningkatan dengan rata-rata sebanyak 38,47. Peningkatan yang dapat dilihat pada hasil olah data pretest dan posttest kelas eksperimen, terjadi karena pada tes awal yang dilakukan merupakan tes yang belum diberikan perlakuan proses pembelajaran dengan menggunakan model Auditory Intellectually Repetition (AIR) berbantuan video pembelajaran karena pretest diberikan dengan maksud untuk mengetahui apakah ada diantara siswa yang sudah 
mengetahui mengenai materi yang akan diajarkan dan juga bisa diartikan sebagai kegiatan menguji tingkatan pengetahuan siswa terhadap materi yang akan disampaikan.

Pada tes akhir (posttest), ketika pembelajaran selesai dilaksanakan diperoleh rata-rata 78,56 hasil dari rata-rata tersebut diperoleh dari proses pembelajaran yang sudah diberikan perlakuan dengan menggunakan video pembelajaran model Auditory Intellectually Repetition (AIR).

Perbandingan Hasil Peningkatan Pemahaman Siswa Pada Kelas Kontrol dan Kelas Eksperimen

a. Hasil Perbandingan Pemahaman Siswa Menggunakan Video Pembelajaran

Pembelajaran yang menggunakan video pembelajaran, menghasilkan data bahwa pemahaman siswa pada saat sebelum diberikan perlakuan memang terdapat perbedaan. Untuk pretest kelas kontrol mendapatkan rata-rata 31,89 dan posttest kelas kontrol 57,75 yang sesuai dengan tabel 9 .

TABEL 9

RATA-RATA PRETEST KONTROL DAN POSTTEST KONTROL

\begin{tabular}{|c|c|}
\hline Kontrol & Rata-Rata \\
\hline Pretest & 31,89 \\
\hline Posttest & 57,75 \\
\hline
\end{tabular}

b. Hasil Perbandingan Pemahaman Siswa Menggunakan Video Pembelajaran Model Auditory Intellectually Repetition (AIR)

Setelah mendapat perlakuan pembelajaran yang diperoleh hasil bahwa terdapat perbedaan pemahaman siswa antara kelas eksperimen yang menggunakan video pembelajaran model Auditory Intellectually Repetition (AIR) dan kelas kontrol yang menggunakan video pembelajaran. Untuk pretest kelas eksperimen mendapatkan rata-rata 40,09 dan posttest kelas eksperimen mendapatkan rata-rata 78,56 sesuai yang tertera pada tabel 10 dibawah ini.

TABEL 10

RATA-RATA PRETEST KONTROL POSTTEST EKSPERIMEN

\begin{tabular}{|c|c|}
\hline Eksperimen & Rata-Rata \\
\hline Pretest & 40,09 \\
\hline Posttest & 78,56 \\
\hline
\end{tabular}

Perbedaan perlakuan antara kelas eksperimen dengan kelas kontrol merupakan salah satu pengaruh terhadap hasil belajar siswa, karena pada kelas eksperimen diberikan perlakuan dengan menggunakan model Auditory Intellectually Repetition (AIR) berbantuan video pembelajaran sehingga siswa pada saat pembelajaran berlangsung merasa tidak jenuh. Selain itu, hasil peningkatan pemahaman siswa pada kelas kontrol dan kelas eksperimen dapat dilihat perbedaannya dari rata-rata perhitungan Gain Ternormalisasi yang berfungsi untuk memberikan gambaran umum peningkatan kemampuan pemahaman siswa dan kemampuan pemecahan masalah statistik antara sebelum dan sesudah pembelajaran. Hasil dari perhitungan Gain dapat dilihat pada tabel 11 dibawah ini.

TABEL 11

HASIL RATA-RATA GAIN KELAS KONTROL DAN EKSPERIMEN

\begin{tabular}{|c|c|}
\hline Kelas & $\begin{array}{c}\text { Rata-Rata Gain } \\
<\mathrm{g}>\end{array}$ \\
\hline Eksperimen & 0,64 \\
\hline Kontrol & 0,37 \\
\hline
\end{tabular}

Berdasarkan pada tabel 11 diatas dapat disimpulkan, bahwa pada kelas kontrol meraih hasil rata-rata 0,37 dan pada kelas eksperimen meraih hasil rata-rata 0,64 sehingga terjadi perbandingan yang signifikan antara kelas kontrol dan kelas eksperimen. Gain yang diperoleh dengan cara menghitung dari hasil nilai posttest yang dikurangi nilai pretest lalu dibagi nilai 100 dan dikurangi nilai pretest. Selain itu hasil pretest yang sudah dilakukan pada kelas kontrol yaitu 31,89 sedangkan pada kelas eksperimen yaitu 40,09. Sedangkan dari hasil posttest dapat diketahui ratarata pada kelas kontrol yaitu 57,75 dan pada kelas eksperimen yaitu 78,56. Peningkatan ini terjadi karena kedua kelas tersebut mendapatkan perlakuan yang berbeda. Perlakuan yang berbeda inilah yang menjadi perbedaan peningkatan pemahaman siswa yang berdampak pengaruh pada hasil belajar siswa itu sendiri. Siswa yang mendapatkan perlakuan menggunakan video pembelajaran dengan metode ceramah hanya mendapatkan proses pembelajaran yang seperti biasanya guru pada umumnya, dimana perlakuan ini merupakan perlakuan yang menyebabkan kebosanan pada diri siswa dan faktor keaktifan dalam belajar kurang karena siswa banyak terfokus untuk mencatat dan mendengarkan apa yang disampaikan oleh guru. Hal ini peneliti dapatkan dari hasil pengamatan (observasi) peneliti pada saat proses pembelajaran berlangsung.

Pada kelas eksperimen, perlakuan yang diberikan berupa model Auditory Intellectually Repetition (AIR) berbantuan video pembelajaran, dan dengan penggunaan tersebut dalam pembelajaran khususnya pada mata pelajaran Sejarah sub pokok kehidupan manusia dalam dimensi Sejarah, ternyata terdapat meningkatkan pemahaman siswa, 
hal ini dapat dilihat dari hasil pretest dan posttest yang meningkat setelah diberikan perlakuan menggunakan model Auditory Intellectually Repetition (AIR) berbantuan video pembelajaran. Ketertarikan siswa pun dapat dilihat dari keaktifan siswa pada saat pembelajaran berlangsung. Ketertarikan inilah yang menyebabkan faktor psikologis siswa muncul yaitu salah satunya minat yang timbul dalam diri siswa.

Dengan begitu peningkatan pemahaman siswa antara model pembelajaran Auditory Intellectually Repetition (AIR) berbantuan video pembelajaran dengan pembelajaran yang hanya menggunakan video pembelajaran mendapatkan peningkatan yang signifikan, hal ini dapat dilihat dari hasil pretest, posttest dan gain ternormalisasi dari kedua kelas.

\section{KESIMPULAN}

Terdapat peningkatan pemahaman siswa pada kelas kontrol yang memakai media video pembelajaran memiliki peningkatan sebesar 25,86, sedangkan peningkatan pemahaman siswa pada kelas eksperimen yang memakai model Auditory Intellectually Repetition (AIR) berbantuan video pembelajaran memiliki peningkatan sebesar 38,47.

Peningkatan pemahaman siswa yang menggunakan media model Auditory Intellectually Repetition (AIR) berbantuan video pembelajaran lebih baik secara signifikan daripada pembelajaran yang menggunakan media video pembelajaran.

\section{DAFTAR PUSTAKA}

[1] Azhar Arsyad, Media Pembelajaran, (Jakarta: Raja Grafindo persada, 2004), hal.

[2] Linuwih, S., \& Sukwati, N. O. E. Efektivitas Model Pembelajaran Auditory Intellectually Repetition (AIR) terhadap Pemahaman Siswa pada Konsep Energi Dalam. [Online]. Tersedia: journal.unnes.ac.id/ 2014

[3] Sugiyono, Metode Penelitian Kuantitatif, Kualitatif dan R\&D. Bandung. Penerbit Alfabeta. (2014).

[4] Sudaryono.. Dasar - Dasar Evaluasi Pembelajaran. Yogyakarta : Graha Ilmu. 2012

[5] Munir, Multimedia dan Konsep Aplikasi dalam Pendidikan, Bandung:Penerbit Alfabeta. 2013

[6] Hamalik, Oemar. 1986. Media Pendidikan.Bandung: Alumni

[7] Cheppy Riyana. 2007. Pedoman Pengembangan Media Video. Jakarta: P3AI UPI.

[8] Cecep Kustandi dan Bambang Sutjipto. (2013). Media Pembelajaran Manual dan

Digital. Bogor: Ghalia Indonesia. 